\title{
7. Understanding the Causes of Border Deaths
}

\author{
A Mapping Exercise \\ Kristof Gombeer, Orçun Ulusoy and Marie-Laure Basilien- \\ Gainche
}

\begin{abstract}
'What causes border deaths?' triggers a large variety of views and often opposing - explanatory arguments. Is it the fault of individuals taking risks? Is it the reckless migrant smugglers who wreak havoc? Or should administrations in the Global North express mea culpa for the detrimental effects of their border policies? Rather than arguing in favour of one explanation, this chapter asserts that how border deaths are understood depends on a wide range of interacting factors. We map these factors through five dimensions, which we visualize in an integrated model and illustrate through examples. The five identified dimensions converge towards pathways for analysis of the phenomenon of border deaths without necessarily detracting from other relevant factors and arguments.
\end{abstract}

Keywords: borders, violence, power, physical death, legal death, social death

Because night has fallen and the barbarians haven't come. And some of our men just in from the border say there are no barbarians any longer. Now what's going to happen to us without barbarians? Those people were a kind of solution.

(Cavafy 1975: 18-19)

Cuttitta, P. \& Last, T. Border Deaths: Causes, Dynamics and Consequences of Migration-related Mortality. Amsterdam: Amsterdam University Press, 2020.

DOI: 10.5117/9789463722322_CHO7 
While the violence associated with the borders of the Global North has become more salient and visible (Jones 2017), studies on its causes and effects remain scattered. What is clear, however (also from the chapters of this volume) is that the phenomenon of border deaths cannot be analysed and understood through single concepts, arguments or points of view. Not only are there several ways in which one can understand the respective roles of actors, policies, practices and geographies in causing border deaths, but also the very meaning of the word 'border death' raises a variety of issues (see Chapters 3 and 6).

Do people die because of the methods employed by smugglers? Do people die because they take too much of a risk when embarking upon their journey? Are deaths at the border the result of policies made in the capitals of the Global North? Furthermore, what do we mean by the term 'border death'? And does it only cover people 'at' the border, or can borders also cause violence before and after the border?

In light of these questions, we propose to map certain dimensions of the phenomenon of border deaths, its causes and effects, and how one can understand them: 1) the (violent) effects of borders; 2) how knowledge about the phenomenon is produced and by whom; 3 ) the different actors involved; 4) the geo-temporal context; and 5) the level of analysis of border violence. The combination of these five dimensions can be used to situate the large variety of issues and arguments that circulate in the field. It is not the ambition of our mapping tool to be exhaustive or to provide an extensive literature review. Its practical target is to situate diverging analyses of the border deaths phenomenon vis-à-vis each other in a comprehensive way.

The next section provides a description of the five dimensions. Through three examples, we subsequently show how the combination of the identified dimensions converges towards pathways for analysis into the phenomenon under scrutiny, without detracting from other relevant aspects.

\section{Five dimensions of the causes and effects of border deaths}

\section{Effects}

A first dimension that affects how one understands the phenomenon of border deaths concerns what one considers to be the negative externalities of borders and the extent to which they relate to border death: what are the violence-producing effects of borders in general, and what falls under the notion of the effect called 'border death' in particular? At first glance, the 
answer to the latter question 'what is a border death?' seems straightforward: the effect of physical death of a person crossing a border, who drowned, suffocated, fell, froze to death, was struck by a vehicle, was shot or got dehydrated, at the border. But the notion of 'border death' can be problematic and connotes many more things. What the word 'border death' signifies for someone will depend on a lot of factors (see below on the 'Analytical Lens' dimension). Someone with a legal world view or a certain philosophical approach will read different things into the word 'border death'. The same goes for the medical or social scientist. In addition to physical death then, there are at least two other ways of understanding the term 'border death': 'legal death' and 'social death'.

Traditionally, the 'legal death' concept is used for persons who are either lost after an accident at sea or in uncertain circumstances (e.g. in a very remote area or in a war zone). While the definition of legal death may differ from one domestic legal system to another, there are two important elements of the term: firstly, the person must be lost in a clearly dangerous event and secondly, a certain period must pass without any information transpiring that the person is alive. In border death cases, a legal border death is a migrant who is missing during the border crossing and whose body is never found or identified, a situation which is then post-factum reified (see Chapter 5). This notion of border death can of course coincide with physical border death.

'Social death' in the border context can refer to a person not having access to a social contract or to minimum protection offered by law as a result of how borders manifest themselves vis-à-vis a person. Social death can refer to people not accepted as fully human by society in general (Card 2005; Bauman 2007) and take the shape of a lack of protection in particular circumstances: not being protected by law against abuses and violence from different actors while en route, or not having any real meaningful access to protection by the government when, for instance, a person has already arrived in the destination country (see Chapter 6). The non-recognition as a person by society, within the violent borders context, reduces them to numbers (or barbarians at the gates) and provides states with arguments to elude their responsibilities to protect lives at their borders. The examples above show that people may encounter physical, legal and/or social death not only at the border, but also before or after (and because of) the border imposed upon them (see below on the 'Geo-temporal context' dimension).

The power and violence inherent to borders can thus give rise to a different kind of 'death': physical, legal and social. How one understands the concept of 'border death' is inter alia affected by the one producing 
knowledge about it (for a detailed discussion on representation, see Chapter 3). This, in turn, affects how one produces knowledge of it and where one will look for answers and methods when trying to understand and explain how borders give rise to violence and border deaths.

\section{Analytical Lens}

The second dimension concerns those that are doing the thinking about the causes and effects of border deaths. The group of people contributing to knowledge about border deaths is highly diverse. It consists inter alia of academics, people who work(ed) for NGOs or who work(ed) for IGOs, as well as politicians and policy makers. There is also - and not to be overlooked - the migrant him- or herself.

All sorts of factors are at play when these different actors produce knowledge on the subject (Chapter 3). For instance, and to name just one, the educational or vocational background of a person plays a role in shaping how one makes sense of certain concepts (as discussed above under the 'Effects' dimension). For example, the term 'death' will trigger a different meaning for a medical doctor (e.g. head trauma or suffocation caused death) than for a social scientist (e.g. restrictive border controls make border crossings deadlier). It moreover goes without saying that within certain epistemic approaches, such as social science, heavy debates may exist about how one can know things in the first place (Jackson 2011).

Whichever way one puts it, the analytical lens will differ depending on who is doing the thinking and what the person will want to focus on, when trying to unearth the dynamics behind border deaths. At least four different lenses circulate through which one can understand border death: the scientific (e.g. life sciences, forensic sciences or social sciences), the ethical, the legal, and the experience-based view. Each perspective produces different insights on how to grasp the concept of border deaths and what its drivers are (e.g. pathological factors, bad policies, smugglers who force people into their predicament, legally liable states, morally flawed decisions made by polities in the Global North, etc).

Take for example the lawyer who uses a legal lens to scan for and pick up different elements and uses different terminology and methodologies in order to understand and analyse instances of border deaths. The lawyer sees legal borders and entities which can be given all sorts of legal labels. For the lawyer, a certain actor can for instance be said to be liable for the loss of life at the border if certain legal criteria are met. The epistemic potential of lawyers is not limited to determining what the law has to say about this or that border incident: they can contribute to social science, for instance by 
helping to gain insights on how border policies and practices can undermine rights claims. Compare this to the social scientist (scientific lens) who may look for statistically significant relationships between certain variables (e.g. EU migration and border control policies) and border deaths and who will use qualitative methods to further understand the causes and effects. We could similarly produce examples from search and rescue professionals, forensic pathologists, political economists, criminologists, etc.

The epistemic background of the person doing the analysis will not only influence what he or she qualifies as a border death, but also where and at what level of analysis one should look for the driving forces behind border deaths (see below on the 'Geo-temporal context' and 'Level of manifestation' dimensions) or on which actors to focus on in order to understand the causes of border deaths. This brings us to the following dimension.

\section{Actors}

The third dimension of our map addresses who we consider as a subject of analysis when trying to understand the border deaths phenomenon. In other words: who causes border deaths or should (at least partly) be included in the equation? A long and non-homogenous list of individuals and public and private bodies are involved in the border deaths phenomenon (see Chapter 1 for a detailed outline of actors in the 'border death regime'). These actors have different roles in causing border deaths and are differentially, directly or indirectly, affected by them.

In broad terms and with the necessary nuances, one can distinguish between migrants, migrant social networks, smugglers, humanitarians, and official actors in the state of origin, transit or arrival. Studying each of these in the chain of events can lead to valuable insights; studying different actors invites different claims about the causes of border deaths. The latter underscores the importance of allowing different analytical lenses to illuminate the issues at stake (see above): for instance, people with different disciplinary training or with different experiences may pinpoint the relevance of actors other than criminals who constitute one of the prime categories of actors to focus on for criminologists and law enforcement authorities.

Categories of actors are not as homogenous or fixed as they are often presented. For example, as studies suggest, many smugglers are actually migrants themselves (Ahmad 2011; van Liempt and Sersli 2013; Baird and van Liempt 2016). Smugglers are motivated by different things and act in different ways; their role towards migrants can be labelled as angels (providing opportunities for migrants) or devils (culpable criminals violating all sorts of 
laws) (Horwood 2018a). The interchangeability of labels can be highlighted by the simultaneousness of their roles: a police informer among migrants who is also acting as a facilitator for a smuggler. Another example is that of state institutions: while some state agents are socialized in humanitarian values and have a disposition to prioritize saving lives (e.g. a coastguard officer), others might see border crossers as security risks that have to be controlled. Other state agents may simply abuse their power through corruption or violence.

Analyses may choose to focus on one or more of these actors when inquiring about border deaths. Some studies focus on the border control practices, deterrence and apprehension measures executed by border guards and law enforcement as a - direct - cause of border deaths (e.g. La Coalición de Derechos Humanos and No More Deaths 2016). Others may focus on the role of smugglers whose methods may directly or indirectly cause border deaths, whilst others will focus on the policies, laws, and/or practices of states or regional organizations such as the European Union as indirect causes of border deaths (Last 2018; Ulusoy, Baldwin-Edwards and Last 2019). Analysing the role of a particular actor can lead to diverging claims. Social scientists and lawyers may argue over migrants' risk-taking behaviour, their own role in their death or suffering, while others may point to the restrictions on migrants imposed by government policies which makes routes to the Global North more dangerous for certain groups (Brolan 2003; Spijkerboer 2018; Horwood 2018b). A more holistic approach to investigating actors in relation to border deaths requires a theoretical framework that relates these actors to one another, such as the 'border death regime' introduced by Cuttitta, Häberlein and Pallister-Wilkins in Chapter 1.

\section{Geo-temporal context}

While the question 'where and when does border violence and death occur?' may seem unnecessary (even absurd) at first, the complex nature of the violence arising from borders can be traced back to multiple geographies and timeframes along the migration route (see Chapter 6). As already mentioned, there is some analytical leeway as to what one can consider a border death. On the one hand, one can conceptualize it narrowly to only include deadly crossings at legal and/or geographical borders (Last 2018; La Coalición de Derechos Humanos and No More Deaths 2016; Ulusoy, Baldwin-Edwards and Last 2019; Missing Migrants Project). ${ }^{1}$ On the other hand, from a broader space-time perspective, borders can also give rise to violence and victims before or after people cross

1 The Missing Migrants Project of the International Organization for Migration (IOM) records only 'migrants who die during their journey to a country different from their country of residence' 
them (La Coalición de Derechos Humanos and No More Deaths 2016; Last 2018; Ulusoy, Baldwin-Edwards and Last 2019), including deaths due to 'deportation procedures, detention conditions and the inadequacies of asylum application processes' (UNITED for Intercultural Action n.d.). For instance, the Australian Border Deaths Database 'maintains records of all known deaths associated with Australia's borders' (Border Crossing Observatory 2019). It not only registers physical deaths resulting from dangerous border crossings or interdictions at sea, but also includes other border violence-related effects, such as death resulting from deteriorating health or suicide while in detention.

While the focus of scholarly work is mainly on the violence $a t$ the borders or after the borders (Weber and Pickering 2011), people can sometimes already feel the effects of borders without leaving their country of origin or transit. Borders as such can affect livelihoods (sometimes quite literally) of people, for instance, in countries which are weak visa-states. One might argue it is overstretching the concept of border deaths to consider those that are stuck in societies affected by violence or a lack of access to a safe social contract. Think however, of those cases where third countries refuse to issue humanitarian visas at their embassies in these countries. ${ }^{2}$ If a few weeks later those people die due to the local violence, could they be considered to be border deaths?

One can argue that, with the securitization of migration issues in the Global North and with the externalization of migration policies to third countries (to the countries of origin and countries of transit), violence at the borders is transferred (spread) beyond the geographies of borders (Walters 2006; Cuttitta 2015; Basilien-Gainche 2017b). The geo-temporal dimension as a result includes violence at home, violence in transit, violence when crossing and violence at arrival, covering almost all geographies along the migration route. Although the current chapter does not go into further detail, one should be cautious about capturing the border deaths phenomenon exclusively through classical cartographic methods and visualizations: it may hinder scrutiny and understanding of non-geometric manifestations of authority in the field of border control and migration policies (cf. Rajkovic 2018).

\section{Level of manifestation}

Spending some time at the borders where border deaths occur provides a wide range of points of view on why and how border deaths are happening.

and excludes 'deaths that occur in immigration detention facilities or after deportation to a migrant's homeland'. (https://missingmigrants.iom.int/methodology).

2 CJEU, GC, 7 March 2017, X.X. v. Belgium. Case C-638/16 PPU. See Moreno-Lax 2017a, 2017b; Spijkerboer 2017. 
Insights can focus on multiple levels of analysis, from the micro level, in what could be described as capturing the direct and very tangible causes of death at the borders, to the macro level such as post-colonial structures. Interestingly, these insights at all levels can be in operation at the same time or can be simultaneously linked to a specific border death.

At the lowest level, which one might label the 'micro level', migrants experience what could be described as the direct causes of death at the borders: it concerns tangible experience of violence such as the man-made use of force by smugglers or border- and coastguards, or being subjected to harsh weather conditions. The ways in which borders cause violence however, should be understood in the larger context, since 'power', 'violence', and 'causation' also manifest themselves via other levels (Galtung 1969; Barnett and Duvall 2005; Kurki 2008).

At the 'meso level', one can investigate the role of the policies of states and regional organizations and - in case policies are viewed as an independent variable - how they make (irregular) border crossing legal versus illegal, safe versus unsafe, etc. (see Chapters 1 and 8).

At a more general level - the 'macro level' or 'structural level'- we might examine how global, systemic forces influence the emergence and continuation of border deaths (see Afterword and Preface). Here one can think of studies on how North-South relationships, alleged clashes between civilizations, post-colonial structures, historical-material forces, race, gender, etc. influence the manifestation of borders themselves, constitute identities and norms, and give rise to violence and human casualties.

\section{The interaction of dimensions}

The following three figures bring together these five dimensions in a sort of analytical map - a pentagon - and combine them in different ways. This helps to clarify what people do when focusing on certain aspects and how that does not necessarily exclude assessing the role of other factors contributing to border deaths.

\section{Example 1: Understanding the effect of policies on deaths at the border}

One way of studying border deaths is to inquire whether - and if so: why? there is any significant correlation between the occurrence of border deaths on the one hand, and changes in national, regional or international immigration and border control policies on the other. One such analytical undertaking is that of Last (2018). This academic study focuses on producing reliable data on 
physical border deaths at the southern external land and sea borders of the European Union. She combines the following (aspects of) dimensions to start with: physical deaths (effect) at the border (geo-temporal context) analysed from a social scientific perspective (analytical lens). The next step in her research is identifying hypotheses which capture the relationship between policy (meso level) and the phenomenon of physical border deaths. In this context, Last finds that this relationship is presented differently in academic literature from EU policy documents. While academics point to the causation of things occurring at the meso level (stricter policies lead to irregularization and endangerment and hence more deaths) ${ }^{3}$ and the role of states of arrival (actor dimension), ${ }^{4}$ policy makers emphasize action by migrants and smugglers

\section{Figure 7.1 Understanding the effect of policies on deaths at the border}

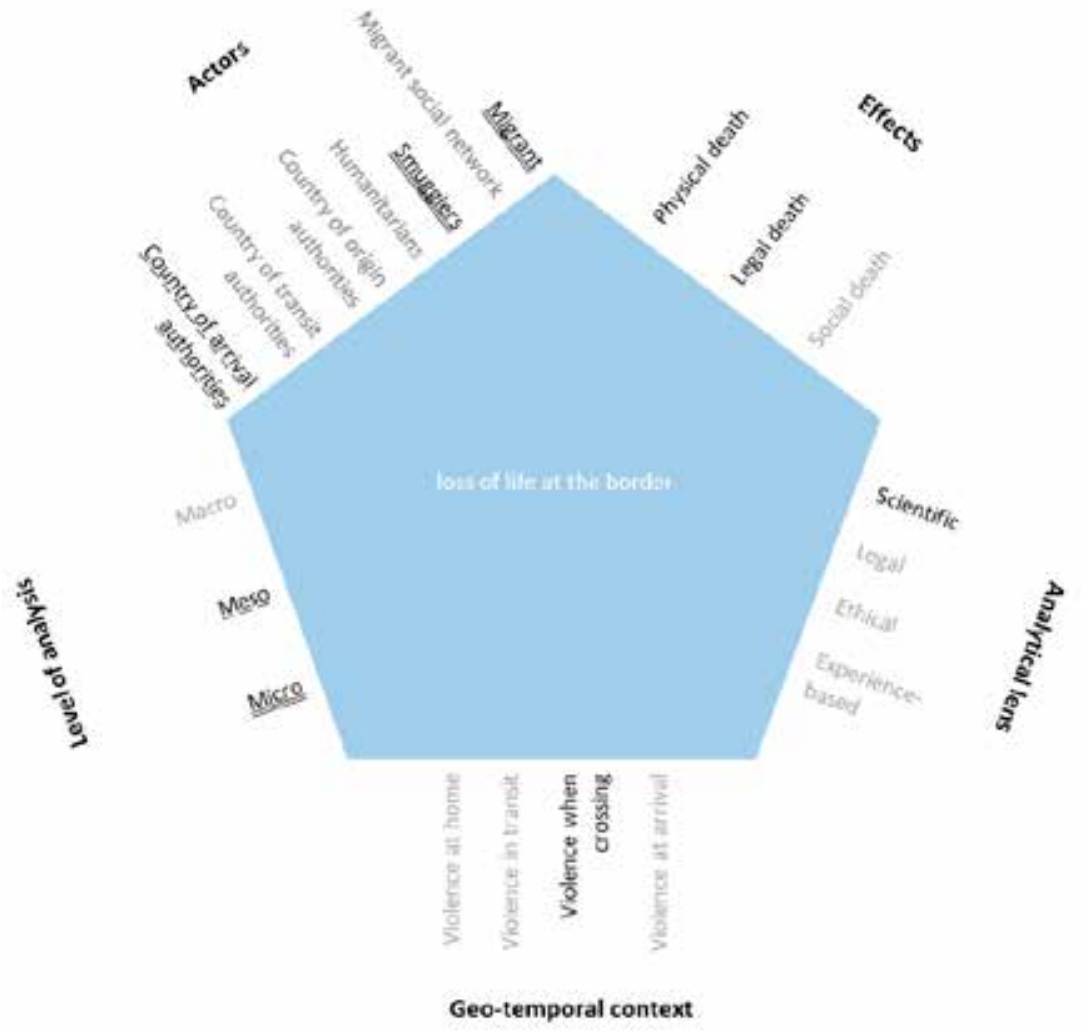

3 Some identify a relation between the two at a macro level too. See Last, 2018: 78-79.

4 Indicated in Figure 7.1 by dash underlining. 
at the micro level (travelling illegally and risk taking, combined with the ruthlessness of smugglers which leads to more deaths) (actor dimension). ${ }^{5}$

\section{Example 2: Understanding border deaths in transit}

While our previous example concerned a study of border deaths at the border, our next example concerns what, from a geo-temporal perspective, could be labelled border deaths before the border. Imagine the physical death of an irregular migrant from Ghana in a Nigerian detention centre. Such deaths are nowadays likely to be reported and/or recorded, but not necessarily as border deaths (see Chapters 2 and 3). Records are likely to qualify the death as the passing of a person due to inhumane conditions of the detention centre in Nigeria and/or malpractice of Nigerian officials (i.e. state actors in the country of transit). A basic understanding of such records will reveal nothing about borders, nothing about Global North-South dynamics which constitute the setting of the border death in our example. Alternatively, consider a Sudanese migrant held in Gharyan prison in Libya who is then sold as a slave. We would term this a social death. Again, there would be no mention of the violence caused by borders.

However, a closer look by a scholar studying the externalization of migration policies will underline certain elements of these death records. Actors such as governmental agencies of these transit countries or armed non-governmental groups would be the first ones to be highlighted. Interestingly, the European Border and Coast Guard Agency (Frontex) would also be highlighted since the European Border Agency provides training, guidance and material to these countries (Ikuteyijo 2014; Campesi 2018).

According to our model, the level of manifestation of border violence and death would include both the meso level and macro level. The relationship between countries, funding mechanisms, regional and bilateral agreements between transit and arrival countries will provide evidence at a meso level. At a macro level, slavery (Stoyanova 2017) would definitely bring race and gender issues forward. A social scientific analysis (e.g. a historical-economic study) could highlight the historical and contemporary role of the Global North in creating political and economic instability in the South, while at the same time barring the mobility of people to the North through its policies and politics of international law. This analysis could also be done from an ethical perspective. On the effects side of our map, the physical and social death of migrants would be the starting point of the analysis while the geo-temporal context would point to transit violence. 
Figure 7.2 Understanding border deaths in transit

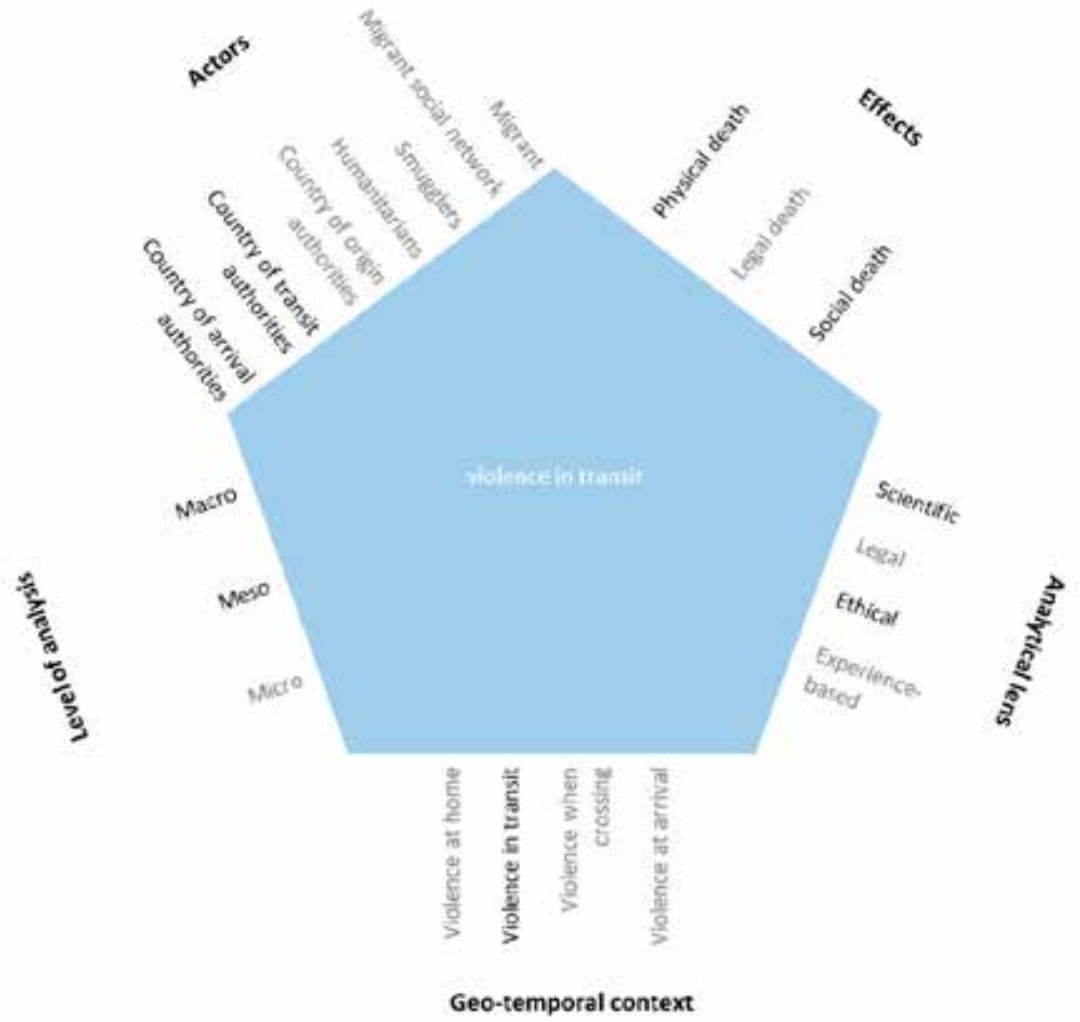

\section{Example 3: Understanding border deaths in the hotspots}

Borders can also give rise to violence and cause death after migrants have reached the destination state, i.e. after they have already crossed the border (Border Crossing Observatory 2019). In September 2018, Médecins Sans Frontières (MSF) reported that there has been an 'increase in suicide attempts among child refugees on Lesvos' (MSF 2018). For many, the violence caused by the borders did not end after crossing the border. On the contrary, so-called 'hotspots' became the border zones themselves (Basilien-Gainche 2017a, 2017c). The actors (according to our map) would include; agencies of the arrival state, i.e. Greece. However, this would only be partially correct. In reality, multiple European Union agencies (such as FRONTEX, EASO) are in charge of these camps in Lesvos as well as humanitarian actors and international organizations (Gkliati 2018). Furthermore, local Greek communities living in these hotspot islands would also be involved, since their lives are fundamentally 
changed by the increased refugee population in their towns and relations between the local community and migrants will profoundly affect the mental well-being of the migrant community, in particular migrant children.

The effects of this border violence would include physical death. However, social death should also be considered since the migrants and refugees living in these islands and camps for more than three years are stripped of their rights by norms and mechanisms of EU institutions and member states that support a policy of non-access. They are simply 'kept' out-of-sight and left to 'die' in these camps.

Greek asylum policies and law would provide a starting point for the analysis, although the meso level of analysis should include the main elements such as the EU-Turkey Statement of March 2016 (Ulusoy and Battjes 2017) and EU migration policies (Steinhilper and Gruijters 2018; Basilien-Gainche 2019). An interesting element to include in the meso level would be the involvement of civil society and international organizations (UN and IOM) in the development of these policies (Geiger and Pécoud 2010, 2014; Fine 2018).

\section{Figure 7.3 Understanding border violence through detention after the border}

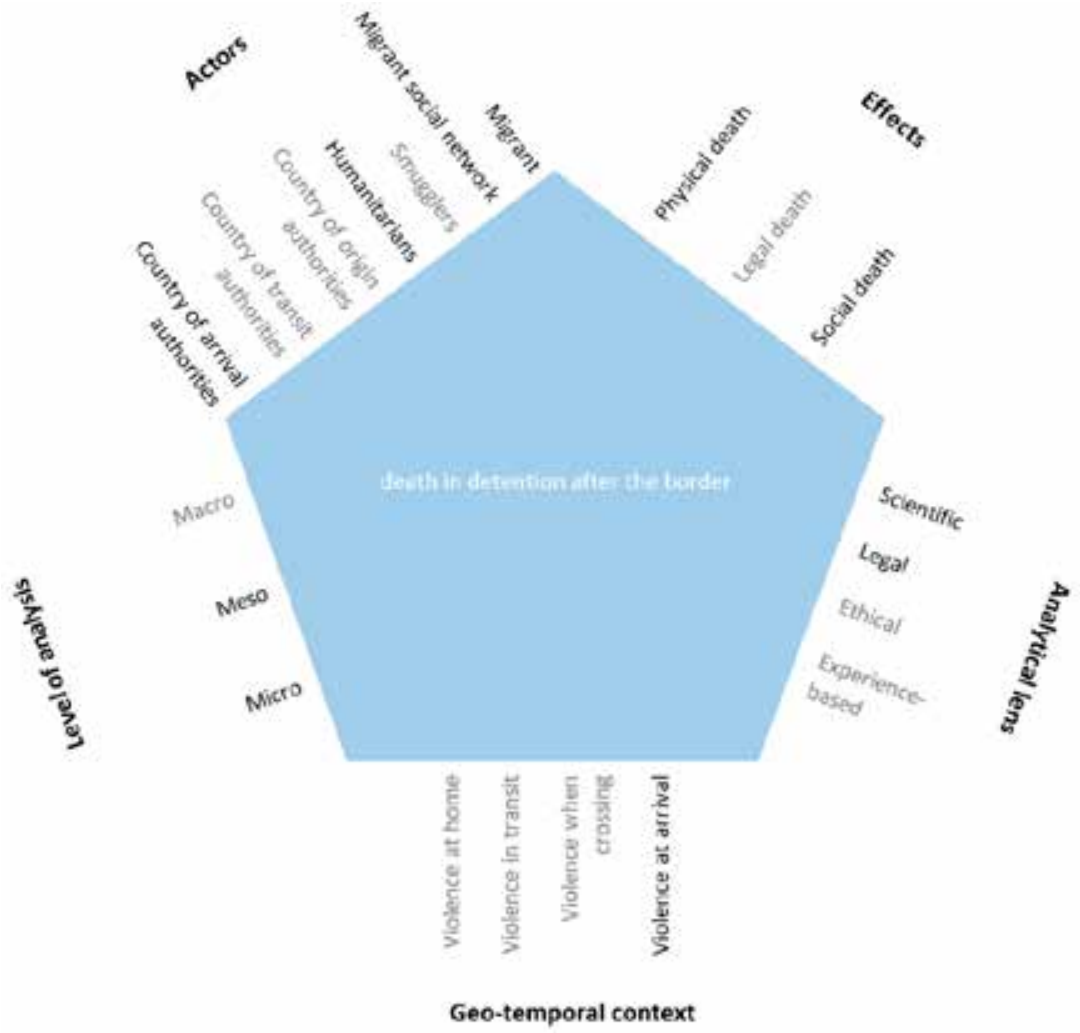


The violence of the border in this example can be analysed from e.g. a legal as well as a social scientific perspective. From a legal perspective, one could identify the legality of the EU-Turkey Statement, EU common asylum system, Greek asylum law in light of wider refugee law and human rights law principles, with the further aim of identifying the legal responsibility of the EU itself, the Greek state, or - at an individual criminal procedure level - the state agents involved in abusive practices.

\section{Conclusion}

How border deaths come about has proven to be quite complex to pin down. Our mapping exercise suggests that several factors are - often simultaneously - at play. Observers should be attentive to this. Indeed, when entering debates about the causes of border deaths, one of the risks is to commence from a position that creates tunnel vision (see Afterword). The advantage of a multi-dimensional perspective (albeit a non-exhaustive one) is that it allows any researcher to situate his or her own thoughts and analyses in relation to others. The researcher does not disagree per se with those others, but may struggle to reach a common understanding because people approach multi-dimensional phenomena from specific positions and select elements accordingly (see Chapter 3). The risk, then, consists of talking past each other. The model raises awareness of the complexity of the causes of border deaths and could therefore help to simplify the communication of different perspectives and to challenge dominant views.

\section{References}

Ahmad, Ali Nobil. 2011. Masculinity, Sexuality and Illegal Migration: Human Smuggling from Pakistan to Europe. London: Routledge.

Baird, Theodore and Ilse van Liempt. 2016. 'Scrutinising the Double Disadvantage: Knowledge Production in the Messy Field of Migrant Smuggling.' Journal of Ethnic and Migration Studies 42 (3), 400-417. https://doi.org/10.1080/136918 3X.2015.1103172

Barnett Michael and Raymond Duvall. 2005. 'Power in International Politics.' International Organization 59 (1), 39-75.

Basilien-Gainche, Marie-Laure. 2019. 'Des migrants disparus à l'Europe déchue. Pour qui sonne le glas?' In: De la crise des réfugiés à la crise de l'accueil. Frontières, droits, résistances, edited by Annalisa Lendaro, C. Rodier and Y. Lou Vertongen, pp. 67-83. Editions La Découverte. 
Basilien-Gainche, Marie-Laure. 2017a. 'Hotspots, Cold Facts. Managing Migration by Selecting Migrants.' In: Migration on the Move. Essays on the Dynamic of Migration, edited by C. Grutters, S. Mantu and P. Minderhoud, pp. 153-171. Leiden: Brill - Nijhoff.

Basilien-Gainche, Marie-Laure. 2017b. 'Les frontières européennes. Quand le migrant incarne la limite.' Revue de l'Union Européenne (609), 335-341.

Basilien-Gainche, Marie-Laure. 2017c. 'Mécanique des flux migratoires \& conception utilitariste des droits. L'approche par les hotspots sous examen.' La Revue Des Droits de l'Homme (11), 138-157.

Bauman, Zygmunt. 2007. Liquid Times: Living in an Age of Uncertainty. Cambridge: Polity Press.

Border Crossing Observatory. 2019. Australian Border Deaths Database. https:// arts.monash.edu/border-crossing-observatory/research-agenda/australianborder-deaths-database (accessed 12 July 2019)

Brolan, Claire. 2003. 'An Analysis of the Human Smuggling Trade and the Protocol Against the Smuggling of Migrants by Land, Air and Sea (2000) from a Refugee Protection Perspective.' International Journal of Refugee Law 14 (4), 561-596.

Campesi, Giuseppe. 2018. 'European Border and Coast Guard (Frontex): Security, Democracy, and Rights at the EU Border.' Oxford Research Encyclopedias 1, 1-32. https://doi.org/10.1093/acrefore/9780190264079.013.354

Card, Claudia. 2005. 'Genocide and Social Death.' In: Genocide and Human Rights, pp. 238-254. London: Palgrave Macmillan. https://doi.org/10.1057/9780230554832_19

Cavafy, Constantine P. 1975. 'Waiting for the Barbarians'. In: Constantine P. Cavafy, Collected Poems, translated by Edmund Keeley and Philip Sherrard $\left(11^{\text {th }}\right.$ edition, 1992). Princeton: Princeton University Press.

Cuttitta, Paolo. 2015. 'Territorial and Non-territorial: The Mobile Borders of Migration Controls.' In: Borderities and the Politics of Contemporary Mobile Borders, edited by A-L. A. Szary and F. Giraut, pp. 241-255. London: Palgrave Macmillan UK. https://doi.org/10.1057/9781137468857_14

Fine, Shoshana. 2018. 'Liaisons, Labelling and Laws: International Organization for Migration Bordercratic Interventions in Turkey.'Journal of Ethnic and Migration Studies 44 (10), 1743-1755. https://doi.org/10.1080/1369183X.2017.1354073

Galtung, Johan. 1969. 'Violence, Peace, and Peace Research.' Journal of Peace Research 6 (3), 167-191.

Geiger, Martin and Antoine Pécoud. 2014. 'International Organizations and the Politics of Migration.' Journal of Ethnic and Migration Studies 40 (6), 865-887. https://doi.org/10.1080/1369183X.2013.855071

Geiger, Martin and Antoine Pécoud. 2010. 'The Politics of International Migration Management.' In: The Politics of International Migration Management, edited by Martin Geiger and Antoine Pécoud, pp. 1-21. London: Palgrave Macmillan. 
Gkliati, Mariana. 2018. 'A Nexus Approach to the Responsibility of the European Border and Coast Guard: From Individual to Systemic Accountability.' SSRN 1-27. https://doi.org/10.2139/ssrn.3118551

Horwood, Christopher. 2018a. 'Angels or devils? A More Honest Appraisal of the Role of Migrant Smugglers.' In: Mixed Migration Review 2018, edited by Chris Horwood, Roberto Forin and Bram Frouws, pp. 122-127. Geneva: Mixed Migration Centre. http://www.mixedmigration.org/wp-content/uploads/2018/11/ Mixed-Migration-Review-2018.pdf (accessed 12 July 2019)

Horwood, Christopher. 2018b. 'Qui audet vincit (He Who Dares Wins) - The Underappreciated Role of Aspiration and Risk-taking Behavior in Relation to Deaths in Transit.' Paper for the conference 'Border deaths and migration policies: State and non-state approaches', Amsterdam, 14-15 June 2018.

Ikuteyijo, Lanre. 2014. 'The Impact of European Union Migration Policies on Irregular Migration in Sub-Saharan Africa.' In: Territoriality and Migration in the E.U. Neighbourhood, edited by M. Walton-Roberts and J. Hennebry, pp. 97-110. Dordrecht: Springer. https://doi.org/10.1007/978-94-007-6745-4_7

Jackson, Patrick Thaddeus. 2011. The Conduct of Inquiry in International Relations. Philosophy of Science and its Implications for the Study of World Politics. London: Routledge.

Jones, Reece. 2016. Violent Borders: Refugees and the Right to Move. London: Verso. Kurki, Milja. 2008. Causation in International Relations. Reclaiming Causal Analysis. Cambridge: Cambridge University Press.

Last, Tamara. 2018. Deaths Along Southern EU Borders. PhD thesis, Vrije Universiteit Amsterdam. https://research.vu.nl/en/publications/deaths-along-southern-EUborders (accessed 12 July 2019)

Médecins Sans Frontières. 2018. 'Greece: Increase in Suicide Attempts Among Child Refugees on Lesvos.' MSF Press Release (17 September 2018). https://www.msf. org.uk/article/greece-increase-suicide-attempts-among-child-refugees-lesvos (accessed 5 June 2019)

Moreno-Lax, Violeta. 2017a. 'Asylum Visas as an Obligation under EU Law: Case PPU C-638/16 X, X v État belge (Part I).' EU Immigration and Asylum Law and Policy blog (16 February 2017). Odysseus Network. http://eumigrationlawblog.eu/ asylum-visas-as-an-obligation-under-eu-law-case-ppu-c-63816-x-x-v-etat-belge/ (accessed 5 June 2019)

Moreno-Lax, Violeta. 2017b. 'Asylum Visas as an Obligation under EU Law: Case PPU C-638/16 X, X v État belge (Part II).' EU Immigration and Asylum Law and Policy blog (21 February 2017). Odysseus Network. http://eumigrationlawblog. eu/asylum-visas-as-an-obligation-under-eu-law-case-ppu-c-63816-x-x-v-etatbelge-part-ii/ (accessed 5 June 2019) 
La Coalición de Derechos Humanos and No More Deaths. 2016. 'Disappeared. How the US Border Enforcement Agencies Are Fueling a Missing Persons Crisis. Part I: Deadly Apprehension Methods.' The Disappeared report series. http://www. thedisappearedreport.org/uploads/8/3/5/1/83515082/fianlpart1.pdf (accessed 5 May 2019)

Rajkovic, Nikolas M. 2018. 'The Visual Conquest of International Law: Brute Boundaries, the Map, and the Legacy of Cartogenesis.' Leiden Journal of International Law 31 (2), 267-288.

Spijkerboer, Thomas. 2018. 'Border Deaths and the Right to Life.' Paper for the conference 'Border deaths and migration policies: State and non-state approaches', Amsterdam, 14-15 June 2018.

Spijkerboer, Thomas. 2017. 'Bifurcation of People, Bifurcation of Law: Externalization of Migration Policy Before the EU Court of Justice.' Journal of Refugee Studies 31 (2), 216-239. https://doi.org/10.1093/jrs/fexo38

Steinhilper, Elias and Rob J. Gruijters. 2018. 'A Contested Crisis: Policy Narratives and Empirical Evidence on Border Deaths in the Mediterranean.' Sociology 52 (3), 515-533. https://doi.org/10.1177/0038038518759248

Stoyanova, Vladislava. 2017. Human Trafficking and Slavery Reconsidered. Conceptual Limits and States' Positive Obligations in Europe. Cambridge: Cambridge University Press.

Ulusoy, Orçun, Martin Baldwin-Edwards and Tamara Last. 2019. 'Border Policies and Migrant Deaths at the Turkish-Greek Border.' New Perspectives on Turkey 60 (1), 3-32. https://doi.org/10.1017/npt.2019.2

Ulusoy, Orçun and Hemme Battjes. 2017. Situation of Readmitted Migrants and Refugees from Greece to Turkey under the EU-Turkey Statement. VU Amsterdam Migration Law Series No. 15. Amsterdam.

UNITED for Intercultural Action. No date. 'Working with the List of Deaths.' https:// www.unitedagainstracism.org/campaigns/refugee-campaign/working-withthe-list-of-deaths/ (accessed 3 March 2019).

Van Liempt, Ilse and Stephanie Sersli. 2013. 'State Responses and Migrant Experiences with Human Smuggling: A Reality Check.' Antipode 45 (4), 1029-1046.

Walters, William. 20o6. 'Rethinking Borders Beyond the State.' Comparative European Politics 4 (2-3), 141-159. https://doi.org/10.1057/palgrave.cep.6110076

Weber, Leanne and Sharon Pickering. 2011. Globalization and Borders. Death at the Global Frontier. London: Palgrave Macmillan. 


\section{About the authors}

Kristof Gombeer is a PhD Fellow of the Research Foundation Flanders (FWO) and is completing his doctoral thesis on migrant rescue and human rights at sea at the Vrije Universiteit Brussels and Leiden University.

Orçun Ulusoy studied law at Dokuz Eylul University in Izmir, Turkey. As a lawyer, he worked on human rights related cases with a focus on migration, asylum and LGBTI rights in Turkey. At the Vrije Universiteit Amsterdam, he acted as coordinating researcher of the project, The Human Costs of Border Control.

Marie-Laure Basilien-Gainche is Professor of Law at the University Jean Moulin Lyon 3. She analyses EU immigration and asylum norms, and their compatibility with international and European instruments of human rights protection, with a particular focus on situations of exception and conditions of marginality. 
